\title{
Crucification of Armenian Genocide
}

\section{Zoltan Papp}

Senior Systems Engineer, Diplomat, Miskolc, Hungary

"Corresponding author: Zoltan Papp (Author of pocketFIT), Senior Systems Engineer, Diplomat, Miskolc, Hungary, Tel: +36 30724 4609; E-mail: zoltan.papp@fugeeonline.com

Rec date: August 21, 2015 Acc date: August 24, 2015 Pub date: August 27, 2015

Copyright: $\odot 2015$ Papp Z. This is an open-access article distributed under the terms of the Creative Commons Attribution License, which permits unrestricted use, distribution, and reproduction in any medium, provided the original author and source are credited.

\section{Image Article}

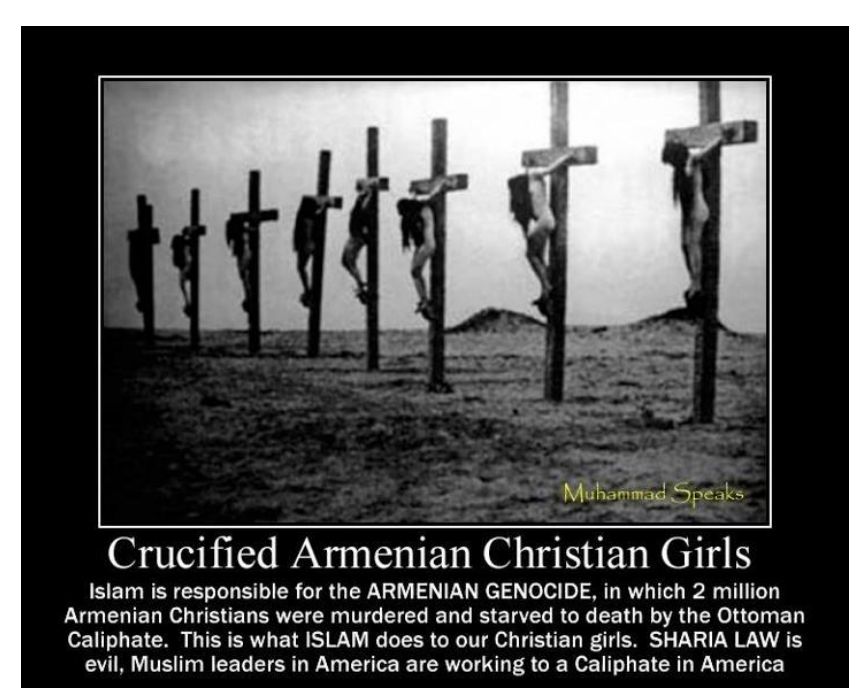

Figure 1: Armenian Genocide1915Anno.

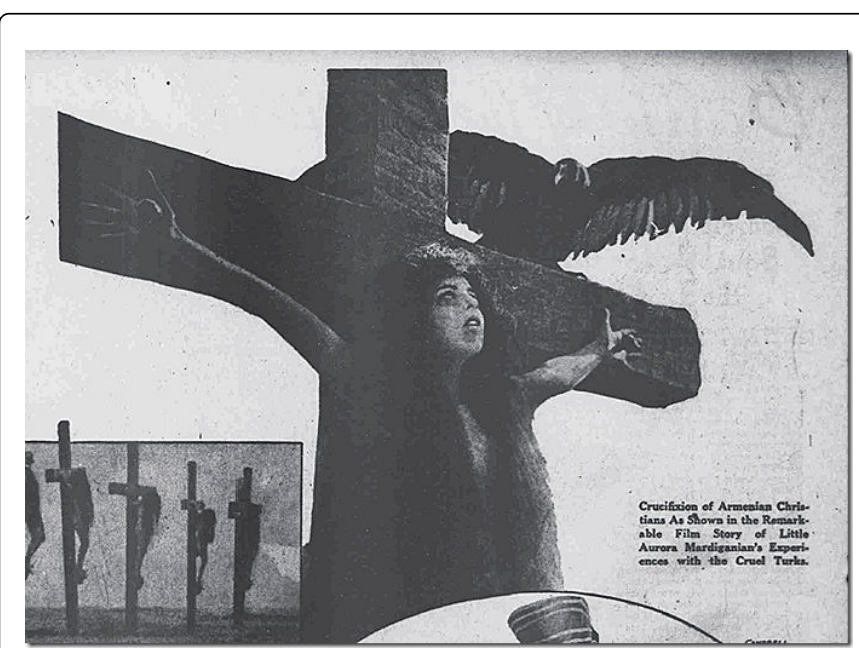

Figure 2: Crucification of Armenian Genocide.

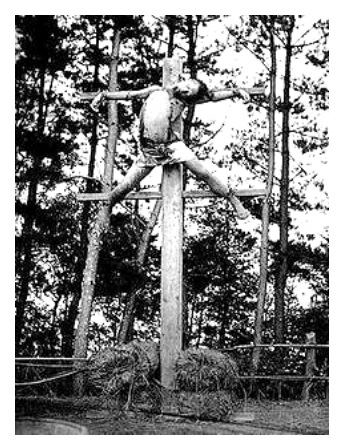

Figure 3: Armenian terrorism.

This research material is on ISIL, the collapse of the Soviet Union and the Armenian genocide of the Armenian girls!

Missing time axes. It is well known that the Armenian genocide was in 1915. However, we have seen it in the news that those terrorists of the Armenian genocide in 1915 did very similar acts, in fact, looking the same terrorism in Iraq in 2015 as in Armenia in 1915 [Photos attached!] In fact, the following concern arises. Since the collapse of the Soviet Union was in 1991, after which there was the war against the Chechens and the Balkan war in 1994. The question is this! Considering that some of those photos, even on which the crucified girls are, were those terrorist attacks, crucification done at later times? In 1996 or 1997 maybe? This possibility has risen from the fact that several strange cases were reported in the news at that time. For example, people in Moldova (neighbour of Romania) were eating human liver due to poverty supposedly.

Taking the chance, I would also like to note that the date of several historic events were not recorded properly, in fact were misdated in history. Regarding dates and calendar time, we might also note that the Hebrew calendar is over 5,000 years old by now while the Chinese calendar is beyond 10,000 years in date by now. This also means, that Christ was crucified 2015 years ago and our current calendar that most people use today are used in the East as well in the West. Meaning that the crucification of Christ was a base to use the calendar on both East and West of the globe, regardless of Asian, Muslim or any other origin in fact. This also rises the concern, that various other time axes have lost sight along our history. Is ISIL all over the place than by these terrorist acts? What are their common origin in fact if there is such? (Figures 1-3).

${ }^{*}$ The attached photos and historic documents are owned by their respective owner! 